\title{
Whether and What to Offshore?
}

\author{
Jensen, Peter D. Ørberg; Pedersen, Torben
}

Document Version

Final published version

Publication date:

2007

License

CC BY-NC-ND

Citation for published version (APA):

Jensen, P. D. Ø., \& Pedersen, T. (2007). Whether and What to Offshore? Center for Strategic Management and Globalization. SMG Working Paper No. 4/2007

Link to publication in CBS Research Portal

\section{General rights}

Copyright and moral rights for the publications made accessible in the public portal are retained by the authors and/or other copyright owners and it is a condition of accessing publications that users recognise and abide by the legal requirements associated with these rights.

Take down policy

If you believe that this document breaches copyright please contact us (research.lib@cbs.dk) providing details, and we will remove access to the work immediately and investigate your claim. 


\section{Whether and What to Offshore?}

Peter D. Ørberg Jensen

Torben Pedersen

SMG WP 4/2007

March 2007 
SMG Working Paper No. 4/2007

March 2007

ISBN: 978-87-91815-03-4

Center for Strategic Management and Globalization Copenhagen Business School

Porcelænshaven 24

2000 Frederiksberg

Denmark

www.cbs.dk/smg 


\title{
(NOT FOR QUOTATIONS)
}

\section{WHETHER AND WHAT TO OFFSHORE?}

\author{
Peter D. Ørberg Jensen \\ Department of Intercultural Communication and Management \\ Copenhagen Business School \\ Porcelænshaven 18A \\ 2000 Frederiksberg \\ Denmark \\ Email:pj.ikl@cbs.dk \\ and \\ Torben Pedersen ${ }^{1}$ \\ Centre for Strategic Management and Globalization \\ Copenhagen Business School \\ Porcelænshaven 24 \\ 2000 Frederiksberg \\ Denmark \\ Email: tp.smg@cbs.dk \\ Phone: +45 38152521 \\ Fax: +45 38152500
}

${ }^{1}$ Corresponding author 


\title{
WHETHER AND WHAT TO OFFSHORE?
}

\begin{abstract}
In this article, we explore the idea that offshoring of services and technical work should be regarded as a dynamic process that evolves over time. Firms gradually move from offshoring of simple, standardized activities towards offshoring of advanced activities when they accumulate experience with offshoring, and this type of offshoring comes with an entirely different set of characteristics compared to traditional, cost-seeking offshoring. Based on a unique survey among the total population of firms in the eastern region of Denmark, we analyze some of the dynamics of this process through a model that incorporates two different aspects of the process of offshoring. First, we approach the question of whether to offshore and establish a baseline that investigates the determinants of firms' participation-or lack thereof-in offshoring. Secondly, we approach the question of what to offshore and the subsequent process of offshoring, as we analyze the determinants of the offshoring of advanced, highend technical, and service activities. The findings are consistent with the notion of offshoring as a dynamic process as they show how some (cost-related) determinants play a role when firms first engage in offshoring, while rather different determinants matter for the subsequent process of offshoring of advanced activities. Although the model portrays a simplified expression of the offshoring process with two stages, the findings underpin our view that a process perspective on offshoring is a useful analytical framework.
\end{abstract}

Keywords: Offshoring dynamics, and service offshoring 


\section{WHETHER AND WHAT TO OFFSHORE?}

\section{I ntroduction}

Throughout the scholarly publications, government reports, and empirical studies from recent years, there seems to be general consensus that the novelty of the offshoring phenomenon is enabled by the combination of a range of factors that have brought new elements into the equation: in particular concerning the offshoring of services (i.e. administrative and technical work). The mix of trade liberalization, economic and regulatory reform in many emerging economies, advances in information and communication technology, reductions in the costs of the use of these technologies, and the availability of a skilled labor reserve in emerging economies has proven to be very powerful. Not least among the list of enabling factors is the change in the very "DNA" of what a service is. This is aptly coined by UNCTAD (2004) as "the tradability revolution" and vividly described by Karmarkar (2004): namely the fact that many types of services - thanks to digitization - can be stored for later use and no longer require the presence and proximity of user and supplier.

Firms have been offshoring manufacturing operations for many years, typically to low-cost countries. A critical change in MNC strategies over the past five years has been the rapid growth in offshoring of services (UNCTAD, 2004). Whitecollar, skilled jobs in services (mainly back office functions) are now following blue-collar jobs in manufacturing (e.g. Bardhan and Kroll, 2003; Dossani and 
Kenney, 2004). In fact, several authors have emphasized that the recent increase in offshoring of services are qualitatively different from the offshoring of manufacturing and denote it "The New Wave of Outsourcing" (Bardhan and Kroll, 2003) and "The Next Wave of Globalization" (Dossani and Kenney, 2006).

Several authors have pointed out that there seems to be a shortage of research that aims to develop or seeks to contribute to the development of a coherent theory able to capture recent years' evolution in offshoring of business activities, especially concerning the offshoring of services (e.g. Levy and Sturgeon, 2005; Mol et al., 2005). This is not to say that previous work has not been linked to theory, as offshoring has been interpreted in view of e.g. various theories of the firm such as transaction cost theory and the resource-based view of the firm. But, previous work in the field has primarily viewed offshoring through the lens of the established business economics "toolbox" and less as a topic that calls for the establishment of a theoretical framework founded on its own merits. Moreover, the "toolbox" has generally been applied to explain the initial to engage in offshoring whereas later stages of the offshoring process have only received limited attention. As a result, we know far more about the antecedents of offshoring than about the subsequent development and process of offshoring.

However, a few scholars have studied the process of offshoring. Maskell et al. (forthcoming 2006) show that experience is a key determinant in firms' decisions and behavior regarding offshoring and that offshoring to low-cost countries is best described as a learning-by-doing process in which the offshoring of a firm goes through a sequence of stages towards sourcing for innovation. Also, 
Dossani and Kenney (2003) discuss the changing priorities and behavior in connection with U.S. firms' transfer of back-office functions to India. Here, the changes over time are captured in the article's title, which states that offshoring firms "went for cost" when they first offshored back-office functions to India, but in the longer run "stayed for quality", upon gaining experience in the field².

While our arguments in this respect are framed as a conceptual discussion, there is evidence in business practice, too, that a new offshoring paradigm is emerging. Recently, IBM's Chief Executive Officer, Samuel J. Palmisano, published an article in Foreign Affairs where he presents the view that "the globally integrated enterprise" is the firm configuration that will prove to be sustainable in the future due to a variety of reasons. Mr. Palmisano's view is very similar to our view when he describes the strategic drivers and decisions that underpin the offshoring activity:

“These decisions are not simply a matter of offloading non-core activities, nor are they mere labor arbitrage. They are about actively managing different operations, expertise and capabilities to open the enterprise up in multiple ways, allowing it to connect more intimately with partners, suppliers and

\footnotetext{
${ }^{2}$ However, Dossani and Kenney (2003) pose a question mark after the statement that firms change priorities over time and stay in India due to the quality of the services delivered. They highlight the importance of costs as the fundamental driver in offshoring, and although the BPO (business process outsourcing) trend is linked to an increased willingness to outsource core activities, high-end activities in firms' value chains are still largely kept at home as the supply base in low-cost countries is not sufficiently capable at handling such activities.
} 
customers and, most importantly, enabling it to engage in multifaceted, collaborative innovation" (Palmisano, 2006).

The contribution of this article is to show empirical data that support the point mentioned above that offshoring should be regarded not as a static but as a dynamic process that evolves over time. To capture part of these dynamics, we investigate two stages of the offshoring process. First, we approach the question on whether to offshore. Based on data from a large survey among firms located in Denmark, we establish a baseline that investigates the determinants of firms' participation-or the lack hereof-in offshoring. Secondly, we approach the more dynamic question on what to offshore. Among those firms that do engage in offshoring, we analyze the determinants of the offshoring of advanced, high-end technical, and service activities (the notion of "advanced" activities, which is core to the analysis, is outlined in more detail below). Thus, the dynamics of the offshoring process is here translated into two distinct models: first a model that covers the drivers behind firms' participation-or non-participation, as the case may be-in offshoring, and then a model that covers the extent to offshore advanced activities given the initial decision to engage in offshoring.

The remainder of this paper is structured as follows: The next section outlines theoretical background and considerations and develops hypotheses to be tested. It follows by the presentation of the methodology including description of the data used and operationalization of variables. Finally, the results are presented and discussed in the succeeding sections. 


\section{Theoretical considerations and hypothesis development}

\section{Key terms in the field}

The academic literature-as well as the broader debate on offshoring-use different terms when describing and analyzing the offshoring phenomenon. This is generally inconsistent and, at times, confusing. This is most likely the symptom of a dynamic, emerging field where consensus not yet has been reached for established terminology, although the terminology applied by UNCTAD (2004) - as shown below-seems to be the reference point.

\section{*** INSERT TABLE 1 ABOUT HERE $* * *$}

We use the term "offshoring" to denote both firm-internal and firm-external relocation of activities to a foreign country, but in reviewing the literature, it becomes clear that various authors use different terms (e.g. the term "global sourcing" is often used for the same thing). We thereby distinguish this article from the strand of outsourcing literature that specifically and exclusively addresses the make-or-buy decision in the context of the home country. Clearly, offshoring is linked to the make-or-buy decision and underlying considerations, as well as many of the same managerial challenges. Nonetheless, offshoring goes beyond the make-or-buy decision as it adds the cross-border aspect; it is the latter dimension that is the focal point of this article. For the purpose of this article it should be noted that we have kept the terms used by the authors, but we have only included literature that-at some level-concerns the transfer, 
execution, and delivery of activities away from the home country (either to offshore locations owned by the firm or to external, third-party suppliers).

\section{Determinants of offshoring}

There is no standard template that companies can apply to respond to the challenges and opportunities of offshoring and globalization. Companies have a range of strategic options from which to choose when eyeing global opportunities. These strategic courses of action hinge upon the administrative heritage, management philosophy, competences, as well as external conditions like customer preferences and the position of competitors. However, while it is crucial for managers to consider offshoring strategies and decisions in the context of the individual firm and act accordingly, scholars have described a range of factors within the firms and in their business environment that, overall, go together with the firms' participation-or non-participation-in offshoring. These factors are the determinants of firms' participation in offshoring in the sense that there is a proposed causal relationship between these factors and the propensity of firms to offshore business activities.

In the International Business literature offshoring took off as a research field in the 1960s along the emerging phenomenon of offshoring of labor-intensive manufacturing processes by U.S. MNCs to low-cost production zones in developing countries such as Mexico and the Philippines. The offshoring surge was induced by the establishment of tax-exempted and tariff-free export production zones in a number of developing countries in tandem with the US government's introduction of tariff provisions permitting duty-free re-entry to the 
United States of US-made components sent abroad for further processing or assembly (Moxon, 1975). Examples of the offshoring debate include classic contributions such as Stopford and Wells (1972), who pointed out that offshoring is primarily driven and motivated by the use of inexpensive labour particularly in the newly-industrialized countries for export of finished products to other countries. Their assumption was tested and confirmed by Moxon (1975) who applied empirical data to show that offshoring was, at the time, primarily motivated by the use of inexpensive labor in newly-industrialized countries. More recently, authors have repeatedly highlighted the importance of cost advantage as a key driver for and as a determinant behind offshoring. Dossani and Kenney (2004) argue that the potential cost advantage is a fundamental driver behind offshoring. In addition, the need for proximity and the tradability of services determine whether they can be offshored at all, but this boundary is constantly being challenged by the advent of new technologies. Also, Quélin and Duhamel (2003) show, on the basis of survey data, the importance of costs. Their findings show that the most important outsourcing (and offshoring) determinants are first, to lower operational costs; second, to focus on core activities; third, to gain flexibility. Deavers (1997) argues that outsourcing (and offshoring) must be understood as the outcome of a complex change in the cost boundaries facing a firm when it chooses between inside and outside production: home and offshore production, respectively.

However, some authors have also stressed the influence of other factors than cost advantages as determinants of firms' offshoring decisions. Kotabe (1998) points out that in comparing US and Japanese firms, the US firms stress cost 
efficiency in their global sourcing, while Japanese firms put emphasis on non-cost factors like quality, reliability, and product development. Mol et al. (2005) conclude that the propensity of firms to engage in offshoring is a consequence of their ability to search and evaluate foreign suppliers, which is co-determined by firm size, multi-nationality, and frequency of cross-border communications. From a managerial perspective, Karmarkar (2004) points out that offshoring is but one strategic option available to firms. It fits best when firms have simple business processes and produce standardized services, which Karmarkar sees as essential determinants when firms engage in offshoring activities.

Amongst the contributions of previous authors, it is clear that the cost advantage associated with offshoring is seen as the essential determinant behind firms' participation in offshoring. Other factors may play a role, too, but it all begins with the costs. Therefore it is expected that those firms that are mostly exposed to low-cost competition also will be those firms with the highest propensity to offshore their activities. Accordingly, we propose the following hypothesis in line with the overwhelming part of the existing literature:

$\mathrm{H} 1$ The more exposed firms are to low-cost competition the more likely it is that they will engage in offshoring

\section{Determinants of offshoring of advanced activities}

While much of the extant literature on offshoring deals with the determinants that play a role when firms consider "whether" they should engage in offshoring activities, there is an emerging literature on the subsequent offshoring process 
and the determinants that influence offshoring firms when they consider "what" to offshore. Especially two streams of literature stand out as a response to the more dynamic question of what to offshore: one stream is approaching the issue with a business strategy perspective and the other stream takes more of a valuechain perspective.

For the value-chain perspective on the process of offshoring, a useful conceptual framework often applied is found in Porter's theoretical framework "The Value Chain" (Porter, 1985). Within an offshoring context, a value chain analysis serves as a useful platform for identifying activities 1 ) critical to the firm and henceforth which are not obvious candidates for relocation and 2) those activities that qualify for offshoring: typically more standardized and less critical activities. Analyzing the value chain involves disaggregating the organization into the specific activities it performs in creating the products or services valued by the customers or users. As a strategic tool, the value chain analysis can be used to identify and strengthen the core competences that are critical in contributing to the overall strategy while constraining the resource allocation to less critical tasks.

In developed countries, it has often been put forward that companies opt to specialize in creative and innovative activities like $R \& D$, design, marketing and branding while the manufacturing or assembly may be located in more cost advantageous countries (McCann and Mudambi, 2005). Other scholars point out that there are notable differences between offshoring of goods ans services. 
UNCTAD (2004) summarize these differences in four points (p. 152): 1) It is structurally simpler to offshore services in terms of resources, space and equipment requirements; 2) The offshoring of back office services potentially affects firms in all sectors and may have wider implications than offshoring of manufacturing; 3) It affects mainly white-collar jobs whereas the relocation of manufacturing involved primarily blue-collar jobs; and 4) Offshoring of services may be more footloose because of lower capital intensity and weaker links to local suppliers. The bottom-line is that the recent offshoring of services obviously entails new features that distinguish it from the offshoring of manufacturing and it may have wider implications as firms move beyond the cost-driven offshoring of blue-collar jobs to offshoring of white-collar, skilled jobs in back office functions. Furthermore, based on studies of offshoring of services Bardhan and Kroll (2003) suggest that what makes job tasks and activities offshorable are rather the level of standardization. A development in information and communication technology makes it possible to digitise and standardize more and more activities and standardized activities are easier to offshore as they can be codified and be described in detail.

Table 2 exemplifies various activities located on the continuum going from simple and standardized tasks to more complex and advanced tasks. The Table indicates that for each activity, there are a number of tasks ranging from simple (and highly standardized) to more advanced (and less standardized) tasks. 
The idea is that all activities are made up of both extremely complex tasks as well as more simplified activities (e.g. even R\&D includes standardized and routine tasks as tests, patent applications, and documentation).

For the business strategy perspective on the process of offshoring, two contributions are particularly influential as the providers of the fundamental concepts on which many later authors in the field build their arguments. The first influential contribution is Pralahad and Hamel's (1990) article on the "core competences" of the corporation, which argued that firms should concentrate on what they do best-their so-called core competencies-and leave other non-core activities to suppliers. Second, Quinn and Hilmer's (1994) notion of "strategic outsourcing" has greatly influenced the considerations of managers and scholars alike concerning what to outsource (and offshore) and what not to outsource (and offshore). Their overriding purpose of the notion of "strategic outsourcing" is to provide the firm guidance in identifying its strategic core as well as identifying other activities necessary to attain the firm's strategic goals. Central to Quinn and Hilmer's argument is that firms will "maximise returns on internal resources by concentrating investments and energies on what the enterprise does best". They argue that the case for outsourcing is that "perhaps the greatest leverage of all is the full utilisation of external suppliers' investments, innovations, and specialized capabilities that it would be prohibitively expensive or even impossible to duplicate internally".

Under the direct or indirect influence of these two contributions, a number of authors have analyzed and discussed issues related to this second stage 
concerning the offshoring of advanced business activities, and they have in this respect pointed out firm-internal and firm-external determinants of their offshoring behavior. Linder et al. (2003) point out that firms with high R\&D and innovation intensity can extend resources and opportunities by sourcing innovation activities to other firms. Therefore, it is advantageous for such firms to go beyond the traditional non-core outsourcing paradigm. However, somewhat contrary to these views, Martin and Salomon (2003) have shown in an empirical study that if the degree of "tacitness" of activities is high (often the case with advanced, non-codifiable business activities), transfers of technology and knowledge become inefficient and ineffective. As a consequence, the level of tacitness becomes a determinant of offshoring behavior, as firms lack incentives to move activities of this nature offshore. Foss and Pedersen (2002) also address the nature of the business activities involved in offshoring. But instead of focusing on the characteristics of knowledge as determinants of knowledge transfer within MNCs, the authors conclude that the levels of knowledge in subsidiaries, the sources of transferable subsidiary knowledge, and the organizational means and conditions that realize knowledge transfer are the relevant determinants of knowledge transfers within MNCs.

Somewhat along the same lines as Linder et al. (2003), Mol et al. (2004) demonstrate how advanced business activities can go hand in hand with offshoring. The authors show that offshoring is positively linked to the level of product innovation. This means that innovative tech firms do not offshore less. They offshore differently to tap knowledge from specialized sources around the world. They also conclude that high asset specificity forces firms to look beyond 
the home country for highly specialized supply sources. When the uncertainty of input volume is high, firms seek to condense supply chains by prioritizing local suppliers and limiting the number of countries they source from. In addition, when technological uncertainty (i.e. frequent changes in specifications and technology) is high, firms seek to reduce uncertainty by seeking best-in-class suppliers around the world. In a more recent article, Mol (2005) concludes that although R\&D intensive firms traditionally are deterred from outsourcing, such firms are increasingly relying on partnerships with outside suppliers. The importance of alliances and relations with external partners is increasing as a determinant of R\&D intensive firms' outsourcing behavior. Similar to Mol et al. (2004), Murray and Kotabe (1999) use an approach inspired by transaction cost economics to investigate the sourcing strategies of U.S. service firms. Murray and Kotabe find that there are three key determinants in the sourcing strategies of U.S. service firms. First, tapping into the best available supplier is a strategic priority. Second, firms with high degree of asset specificity and inseparable supplementary services accentuate the need for internal sourcing (i.e. maintenance of vertical integration) in order to ensure tighter control. Third, the lower the transaction frequency of services that involve high asset specificity is, the higher the level of internal sourcing.

Much of the public and political concern in advanced economies over the offshoring of advanced technical and service activities to low cost countries is rooted in the perception that the firms and labor force in these countries are now able to outperform domestic firms in advanced economies with services of comparable quality but at a much lower cost. However, taking the determinants 
of the offshoring of $R \& D$ activities to developing countries as a yardstick for this trend, it is, according to Reddy (2000), not the case that advanced economies are being sidestepped in favor of developing countries and emerging economies. It is mainly only MNCs dealing with new technologies which have carried out higher-order $R \& D$ in developing countries, and the overall magnitude of this type of activity is marginal. The primary driving forces are both technology-related (gaining access to R\&D staff) and cost-related (exploiting cost differentials between developing and industrialized countries).

Although, there is currently no consensus concerning what the most important determinants of the offshoring process are, it is clear that the subsequent process of offshoring and the offshoring of more advanced activities are driven by a different logic than the simple cost efficiency. Therefore, we propose the following hypothesis:

H2 The more exposed firms are to low-cost competition the less advanced (or more standardized) activities will they offshore

The two hypotheses - $\mathrm{H} 1$ and $\mathrm{H} 2$ - are formulated in order to investigate both the whether and what questions in offshoring. First, $\mathrm{H} 1$ concerns the role of costrelated in determining firms to participate--or to not participate-in offshoring. Second, $\mathrm{H} 2$ concerns the role of cost-related factors in determining offshoring of advanced activities (given the initial decision of offshoring). Taken together, the two hypotheses will explore to what extent do the same (cost-related) determinants drive the initial stage of offshoring as do the subsequent process of 
offshoring where more advanced activities are offshored. As proposed, it is expected that cost-related factors will facilitate the initial decision to offshore $(\mathrm{H} 1)$, but hinders the subsequent offshoring of more advanced activities ( $\mathrm{H} 2)$.

\section{Methodology}

\section{Data Compilation and Sample Characteristics}

The Danish economy and firms located in Denmark are highly integrated in the international economy and exposed to global economic flows and trends, including offshoring trends. The Danish case may therefore, in our view, be seen as a "critical case" (Yin, 2003) that shows firms' offshoring decisions, characteristics and behaviour in full scale and at a level not likely to be surpassed in other advanced countries. The only factor that could give Danish firms some shelter vis-à-vis offshoring trends is the language factor, which probably deters some firms from offshoring certain business-to-consumer services (e.g. customer service centres). In business-to-business relations, the language factor is not likely to be a deterrent since firms are generally able to operate in English or other foreign languages and many Danish firms with operations abroad have introduced English as the corporate language.

The data material included in this article originates in a study carried out by a team of consultants and scholars (including the authors of this article) under the auspices of the consulting firm Ramboll Management in the second half of 2005. The study was funded by the Danish government Regional Labor Market 
Councils ${ }^{3}$ of the eastern region of Denmark. This region includes 45 percent of the total Danish population in 2005 and 49 percent of national GDP (2003 data). ${ }^{4}$ As such, the results can reasonably be expected to be generally representative for the country as a whole, although the inclusion of the capital city of Copenhagen - with its assumed higher than national average level of internationally-integrated companies - in the survey may possibly bias the data slightly upwards. However, as such upward "metropolitan city bias" can be expected to be present with respect to the level of offshoring among firms, it ought not influence other aspects related to offshoring.

Methodologically, outsourcing of tasks to domestic Danish companies is excluded from the analysis. Moreover, the survey covers the offshoring of existing activities from Denmark only, while investments in new activities - i.e. greenfield FDI - by firms to foreign locations is not included.

The analysis is based on a 1,504 company-strong survey among the total population of companies in the region in the following sectors ${ }^{5}$ :

- Manufacturing

- Utilities - Electricity, gas, and oil

- Transportation

- Financial Sector - Banking/Insurance

- Business Services

\footnotetext{
${ }^{3}$ The Regional Labor Market Councils in Denmark are comprised of local representatives of employer organizations, unions and regional/municipal government representatives and are responsible for the worker retraining and personalized job search assistance in Denmark. They are funded exclusively by the central government's general tax revenue.

${ }^{4}$ Data from the national Danish statistical agency at www.dst. dk., accessed January 7, 2006.

${ }^{5}$ Based on NACE-nomenclature: General Industrial Classification of Economic Activities within the European Community: Manufacturing: 15000-36999, Utilities - electricity, gas and oil: 40000-40999, Transportation: 60000-64999, Financial sector - banking and insurance: 65000-67999, Business services: 71000-74999.
} 
These sectors are characterized by the fact that offshoring of jobs is possible either through the primary activities in their value chain or through secondary activities (e.g. administrative/back-office activities). This selection roughly follows the same lines as the method used by The Danish Economic Council (DEC), a think-tank funded by the Danish government, which in 2004 presented a major study regarding the offshoring of jobs from Denmark, but it is expanded with additional sectors in which Denmark, and in particular its eastern region, is host to large companies where offshoring of back-office functions could be expected $^{6}$. Hence, the analysis only contains sectors in which it is assumed that activities are tradable and location-independent and in principle can be offshored from Denmark.

The total population of companies in the selected sectors is 3,580 , of which 1,504 have been interviewed in the survey. The analysis is therefore highly representative for sector, geography, and size of the companies (i.e. no bias), with companies smaller than 10 employees excluded. In total, the 1,504 firms in the survey constitute $42 \%$ of the entire population of companies in the region.

Official firm statistics in Denmark entail that each firm has a unique identification number. Through the application of this identification code, the survey data for each firm is linked to individual firm data in official databases. This allows for a widening of the range of analysis to include analysis of key figures such as return on equity and capital intensity.

\footnotetext{
${ }^{6}$ DEC selects 54 sectors within manufacturing and 15 sectors within finance and business services. The reason for this selection is that those sectors are primarily relevant in relation to offshoring.
} 
As discussed in the conceptual section, we focus on both the initial decision to offshore and the decision on what to offshore given that firms have decided to offshore in the first place. Obviously, the population relevant for analysis of the initial decision and subsequent decisions are not the same in the sense that those that decided not to offshore in the first place are not relevant in the analysis of later stages of the offshoring process.

\section{Operationalization of Variables}

\section{Model of the choice of offshoring (sample: 1,504 firms)}

Offshoring was measured as a dummy that take the value 1 if the firm indicated that they have moved tasks abroad that previously was conducted in Denmark within the last three years. This variable was measured for all the 1.504 firms that provided usable responses. Among the 1,504 firms, 346 firms (23\%) have offshored activities during the period 2002-2005.

Three variables that indicate the extent to which the firms are sensitive towards costs factors are included. These three cost-related variables are 1) the share of all employees in Denmark that are unskilled (proxy for blue-collar jobs); 2) the share of all employees in Denmark that have a university degree (proxy for white-collar jobs); and 3) assets per employees as a measure of the capitalintensity of the firm (million DKK/employees). The logic behind including these variables is that the higher the share of unskilled workers in the firm the more sensitive it is expected to be towards low-cost competition, while a higher share 
of employees with a university degree is taking as an indication of lesser exposure towards low-cost competition. The capital-intensity is taken as a proxy for the level of investment in machinery and automatization and the more firms invest in automatization the lesser we expect the exposure towards low-cost competition. Therefore, the first variable - share of blue-collar jobs - are expected to be positively related to the propensity of offshoring, while the two other variables - share of white-collar jobs and capital-intensity - are expected to be negatively related to whether firms offshore or not.

Four control variables are included in the analysis and these are: 1) whether the firm is a service firm (dummy, take value $=1$ ); 2 ) firm size measured as number of employees in Denmark in 2000; 3) financial performance of firms measured as return on equity in 2000; and 4) whether the firm is in a (Danish or foreign owned) multinational company. The first variable, control for the fact that service firms might follow a different pattern of offshoring than manufacturing firms and the second and the fourth variables control for firms that have access to more resources (through size or MNC-relation) and therefore might follow an easier route to offshoring. The financial performance is added as a control variable in order to control for whether it is bad performance that force firms to engage in offshoring.

Model for offshoring of advanced activities (sample: 346 firms)

The extent to which advanced activities were offshored was measured on a 5point scale, where $1=$ only standardised tasks are offshored, $3=$ both standardised and advanced tasks are offshored and 5=only advanced tasks are offshored. The 
respondents were asked to indicate this for all the different activities they have offshored (ranging from 1 to 13 activities). The variable was calculated as the mean value on the 5-point scale for all the activities each firm has offshored. The interpretation is that the higher the (mean) value, the more advanced activities are offshored.

The same three cost-related variables as above are also included in this model. The expectation is that the share of unskilled workers will be negatively related to the offshoring of advanced activities, while share of employees with an university degree and the capital-intensity will be positively related the offshoring of high-end activities. In addition, two other variables that reflect the motives are included in the model. The two additional variables are both perceptual measure of the motives for offshoring the activities. The respondents were asked to indicate on a 5 -point scale ( $1=$ no importance and $5=$ extremely important) the importance of lower labour costs and access to new competences, respectively, for the decision of offshoring the focal activity.

Finally, the same four control variables as mentioned above are also included in this model.

\section{Results}

\section{Correlations}

The correlation matrix (including correlation coefficients for all the independent variables) and descriptive data (mean values and standard deviation) are 
provided in Table 3. In order to detect potential problems of multicollinearity, we should look at the correlation coefficients among the independent variables in the models. None of the correlations are above the usual threshold indicating the possibility of multicollinearity (i.e. $r>0.5$ ), confer Hair et al. (1995). In fact the highest correlation coefficient (on $0.43-0.45$ ) is between the share of unskilled workers and the share of employees with a university degree, which is not surprising as both measures have the same denominator. Hence, the data set does not seem to involve problems of multicollinearity.

\section{Model of the choice of offshoring}

We estimated a logistic regression model for the binary choice of offshoring or not. The results of the analysis of the determinants of firms' participation in offshoring are shown in Table 4 . The full model is highly significant (on a 1 per cent level) with a Likelihood ratio of 151.9 and 7 degrees of freedom. All the three cost-related variables have the expected sign of the coefficient, and both the share of white-collar workers and capital-intensity turned out to be (negative and) significant at 1 and 10 per cent, respectively. Share of blue collar workers has the expected (positive) sign, but is insignificant. These results are all in all providing support to $\mathrm{H} 1$ that firms exposed to low-cost competition will have a higher propensity to offshore than other firms.

Among the control variables, two are highly significant. Whether the firm is a service firm or a manufacturing firm play a significant role as a determinant for the participation in offshoring. Still, manufacturing firms participate to a higher extent in offshoring than service firms. Being part of a multinational company is 
a strong driver for offshoring as the global (MNC) network provides easier access to global sourcing. The remaining two control variables were insignificant. This indicates that the propensity to offshore is not related to the firm size or to financial performance. Small and large firms do not differ in the extent to which they offshore activities. As far as financial performance concerned, the data shows no systematic variation which makes it more likely for a high performance versus a low performance firm to offshore.

\section{Model for offshoring of advanced activities}

We estimated an ordinary least square model (OLS-model) to test how advanced the activities are that firms offshore - given that they do offshore some activities. Table 5 shows the results of the analysis regarding the determinants towards offshoring of advanced activities. All the five cost-related variables have the expected sign. The two variables, share of blue collar workers and motivated by lower labor costs, that indicate high exposure to low-cost competition are both significant (at 5 per cent) and negative as expected. The other three variables that indicate lesser exposure to low-cost competition all have the expected positive coefficient, and the share of white collar workers and the motivation of access to new competences are highly significant ( 1 and 5 per cent, respectively), while capital-intensity turned out to be insignificant. Among the control variables, only the service dummy is significant (positive), which shows that service firms tend to offshore more advanced activities than manufacturing when they offshore. These results are all in all strongly confirming $\mathrm{H} 2$ that the exposure to low-cost competition are negatively related to the offshoring of more advanced activities. 
While the analysis in Table 4 above shows the factors that play a role when firms decide whether or not to offshore, the analysis in Table 5 shows the independent variables that play a role for how offshoring firms behave: or more precisely, how they influence the evolution towards offshoring of more advanced activities. The result clearly shows that the variables indicating exposure to low-cost competition have very different impact on the initial decision whether to offshore (positive impact) and subsequent decision on offshoring of more advanced activities (negative impact).

\section{Discussion}

\section{Determinants of offshoring}

The analysis of the determinants of firms' participation or non-participation in offshoring showed that three variables (share of white collar workers, being a service firm, and belonging to a multinational company turned out to be highly significant. However, the fact that the correlations between the remaining five variables and the propensity to participate in offshoring were insignificant still tells us an interesting story about the present status of offshoring from advanced economies. Contrary to the expectation, firm size does not stand out as a determinant, meaning that larger firms (that presumably have more resources available to engage in offshoring) participate in offshoring to the same extent as smaller firms (that presumably have fewer resources available). In that sense, offshoring may be seen as a very "democratic" strategic activity since it is a real opportunity for different types of firms. In addition, the data reveals information 
about the strategies of firms when they engage in offshoring. First, a high level of automation is often considered to be an alternative to offshoring. The analysis shows that capital-intensity is only marginally significant (at 10 percent) indicating that firms with both higher and lower levels of automation in the production process of services and technical work to a similar degree participate in offshoring (a high level of capital-intensity is taken as a proxy for a high level of automation in the firm). Second, both firms with a relatively positive financial performance and firms with less positive financial performance figures participate in offshoring. This indicates that offshoring is not merely a strategy for firms with rather weak financial performance that feel pressured to engage in offshoring in the hope of getting some quick wins and financial breathing space: a bias portrayed in the recent years' media coverage of offshoring. On the contrary, the data indicate it is also an option for firms that have surplus capital (and thus financial "wiggle room") to view offshoring as a long-term business opportunity.

\section{Determinants of offshoring of advanced activities}

The change towards the offshoring of advanced services and technical work is led by a specific segment of the offshoring firms: Service sector firms are more inclined to offshore advanced activities than manufacturing firms. The same goes for larger firms, while smaller firms to a lesser extent engage in this sort of offshoring. Offshoring of advanced services and technical work is generally done by firms with a large portion of highly-educated white collar staff, whereas firms with many blue collar workers are largely absent. Not least, the offshoring of advanced services and technical work is driven by a different strategy; as shown in numerous studies, firms generally and primarily offshore to save costs. But 
when firms offshore advanced, high-end activities, they also offshore to get access to more competences, expand capabilities, and exploit new business opportunities. Moreover, offshoring of advanced services and technical work is done by firms with both relatively positive and negative financial performance. In other words, when firms decide to engage in offshoring, they are generally not under financial pressure, and when they engage in offshoring of advanced activities they are not driven by an immediate financial pressure.

One of the main contributions of this paper is that it clearly demonstrates that the determinants of firms' offshoring behaviour are dynamic and change according to the different stages of the offshoring process. The results of the two offshoring models are compared in Table 6 , which clearly signify that the variables have very different impact on the different stages of the offshoring process. When firms first enter the offshoring process, or conversely, decide not to enter, one set of determinants play a role. At a later stage, during the implementation of offshoring, a different set of determinants shape firms' behavior regarding the offshoring of advanced or less advanced activities. The analysis shows that offshoring is a dynamic process where the determining factors changes during the process.

The arguments and findings presented by Maskell et al. (forthcoming, 2006) are central to our view on offshoring as a dynamic process towards a new offshoring paradigm where experience is a key determinant in firms' offshoring decisions and behavior. We find that precisely because of this dynamic process, the new offshoring paradigm will not totally replace the classic paradigm. The two will 
continue to coexist, as there seems little doubt that, in most cases, firms will initially engage in offshoring due to the expected cost advantages. But once they are in the process, the offshoring experience they gain will function as a bridge they can use to cross the line between the classic and the new offshoring paradigm. Hence, experience will be the key determinant that enables firms to transcend and engage in offshoring in a manner that matches the characteristics of the new offshoring paradigm. As shown in numerous studies, including our data, the primary incentive for offshoring in the classic paradigm is cost-seeking. In the new paradigm, the primary incentive for the offshoring firm is different. Cost advantages may still be important, but the predominant motive for offshoring firms is to improve competitiveness through access to different types of knowledge and skills located elsewhere than in the home country.

In conclusion, if we are right in assuming that a new offshoring paradigm is emerging, then it is clear that this paradigm is a dynamic one with a high level of complexity. Our data indicate that firm behavior changes with the evolution of the offshoring process. Yet, established business economics theories (e.g. transaction cost economics) and the portfolio of academic offshoring literature very much focus on the strategic drivers and determinants at the initial stage of the offshoring process, but only to a limited extent on what happens further down the road.

\section{Limitations of the study}


We have merely investigated two very broad stages of the process - the determinants that matter when firms enter offshoring and those that matter when they are at some stage of implementation - but these stages are not very fine-grained. The offshoring firms are taken as a broad group, but a more detailed breakdown of this group might bring additional insights. If, for example, offshoring experience matters as a determinant of firms' offshoring behaviour because offshoring is a learning-by-doing process, as noted by Maskell et al. (2006), then analyses of firms at various stages of the experience curve (e.g. "newcomers" vs. "mature offshorers") would be expected to show different elements depending on firms' position on the curve. Another process dimension could be shaped by the destination country, where offshoring to other advanced economies might involve process dynamics very different from offshoring to emerging economies. In other words, offshoring is a dynamic process, but we have presently only limited understanding of the dynamics of this process. Our findings may be contrasted with the fact that most studies and theoretical contributions focus at the initial offshoring stage and decisions. Since firms seem to change along the offshoring path, it might be fruitful to take a closer look at those later stages of the offshoring process, both from an empirical and from a theoretical standpoint.

\section{Conclusions}

In the mainstream literature, offshoring is analyzed from a static view that takes account of priorities, behavior, etc., usually at the initial stage of the offshoring process. Such a perspective does not take into account the related dynamic processes in firms at later stages when firms gain experience and learn how to 
make the best of their offshoring activities. In this article we have looked at offshoring from a different perspective and have identified the determinants that shape firms' decisions and behavior at two different stages of the offshoring process. The focal points of the analysis are the determinants that drive firms to initially engage in offshoring, and those that play a role when firms later offshore various types of more advanced activities. These determinants appear to be different at different stages of the process. This finding is consistent with the notion of offshoring as a dynamic process as it shows a change from the initial stage to the later stage of the process.

We have discussed the idea that a new offshoring paradigm is emerging. Data do not allow for a detailed analysis of how this paradigm is played out in offshoring firms. But there are some indications in the data that seem to comply with the nature of the new offshoring paradigm: The motivational drivers are far more complex when firms offshore advanced services and technical work compared to the traditional view on offshoring according to which firms offshore to save costs.

In conclusion, looking at offshoring from the perspective of a dynamic process may be a fruitful analytical framework for future research. However, since we have merely applied a simplified two-stage process, more detailed models of the offshoring process are needed to analyze the process dynamics and characteristics with greater precision. 


\section{References}

Bradhan, A.D. and Kroll, C.A. (2003) 'The New Wave of Outsourcing', Research Report, Fisher Center for Real Estate and urban Economics, University of California, Berkeley.

Danish Economic Council (2004) Danish Economy; Chapter 2, International Outsourcing, Autumn edn, Danish Economic Council: Copenhagen, Denmark.

Deavers, K.L. (1997) 'Outsourcing: A Corporate Competitiveness Strategy, Not a Search for Low Wages', Journal of Labor Research, 18(4):503-519.

Dossani, R. and Kenney, M. (2003) 'Went for Costs, Stayed for Quality?: Moving the Back Office to India', Asia-Pacific Research Center, Stanford University.

Dossani, R. and Kenney, M. (2004) 'Offshoring: Determinants of the Location and Value of Services', Asia-Pacific Research Center, Stanford University.

Dossani, R. and Kenney, M. (2006) 'The next Wave of Globalization: Relocating Service Provision to India', Berkeley Roundtable on the International Economy.

Foss, N.J . and Pedersen, T. (2002) 'Transferring Knowledge in MNCs: The Role of Sources of Subsidiary Knowledge and Organizational Context', Journal of International Management, 8(1): 49. 
Hair, J.F., Anderson, R.E., Tatham, R.L. and Black, W.C. (1995) Multivariate Data Analysis, New Jersey: Prentice Hall.

Karmarkar, U. (2004) 'Will You Survive the Services Revolution?', Harvard business review, 82(6): 100-107.

Kotabe, M. (1998) 'Efficiency vs. effectiveness orientation of global sourcing strategy: A comparison of U.S. and Japanese multinational companies', Academy of Management Executive, 12 (4): 107-119.

Levy, F. and Sturgeon, T.J. (2005) Measuring the Off-Shoring of Service Work and its Impact on the United States. A Working Group on Services Off-Shoring, Summary edn, Massachusetts Institute of Technology: Cambridge, MA, USA.

Linder, J.C., Jarvenpaa, S. and Davenport, T.H. (2003) 'Toward an Innovation Sourcing Strategy', MIT Sloan Management Review, 44(4):43-49.

Martin, X. and Salomon, R. (2003) 'Tacitness, Learning, and International Expansion: A Study of Foreign Direct Investment in a Knowledge-Intensive Industry', Organization Science, 14(3): 297.

Maskell, P., Pedersen, T., Petersen, B. and Dick-Nielsen, J. (2006, forthcoming) 'Learning Paths to Offshore Outsourcing - from Cost Reduction to Knowledge Seeking', Industry and Innovation. 
McCann, P. and Mudambi, R. (2005) 'Analytical differences in the economics of geography: the case of the multinational firm', Environment and Planning, 37(10: 1857-1876.

Mol, M.J. (2005) 'Does being R\&D Intensive Still Discourage Outsourcing? Evidence from Dutch Manufacturing', Research Policy, 34(4):571-582.

Mol, M.J., Pauwels, P., Matthyssens, P. and Quintens, L. (2004) 'A Technological Contingency Perspective on the Depth and Scope of International Outsourcing', Journal of International Management, 10(2):287-305.

Mol, M.J., van Tulder, R.J.M. and Beije, P.R. (2005) 'Antecedents and Performance Consequences of I nternational Outsourcing', International Business Review, 14(5):599-617.

Moxon, R.W. (1975) 'The Motivation for Investment in Offshore Plants: The Case of the U.S. Electronics Industry', Journal of International Business Studies, 6(Fall): 51-66.

Murray, J.Y. and Kotabe, M. (1999) 'Sourcing Strategies of U.S. Service Companies: A Modified Transaction-Cost Analysis', Strategic Management Journal, 20(9): 791-809.

Palmisano, S.J. (2006) 'The Globally Integrated Enterprise', Foreign Affairs, 85(3): 127. 
Porter, M.E. (1985) Competitive Advantage: Creating and Sustaining Superior Performance, First edn, The Free Press: New York, NY.

Prahalad, C.K. and Hamel, G. (1990) 'The Core Competence of the Corporation', Harvard business review, 68(3): 79.

Quélin, B. and Duhamel, F. (2003) 'Bringing Together Strategic Outsourcing and Corporate Strategy: : Outsourcing Motives and Risks', European Management Journal, 21(5):647.

Quinn, J.B. and Hilmer, F.G. (1994) 'Strategic Outsourcing', Sloan management review, 35(4):43.

Reddy, P. (2000) Globalization of Corporate R \& D: Implications for Innovation Capability in Developing Host Countries, First edn, Routledge: London.

Stopford, J.J . and Wells, L.T. (1972) Managing the Multinational Organisation of the Firm and Overlap of Subsidiaries, First edn, Basic Books: New York, NY.

United Nations Commission on Trade and Development (UNCTAD) (2004) World Investment Report. the Shift Towards Services., UNCTAD: Geneva, Switzerland.

Yin, R.K. (2003) Case Study Research. Design and Methods, Third edn, SAGE Publications: Thousand Oaks, CA. 
Table 1: Offhoring and outsourcing

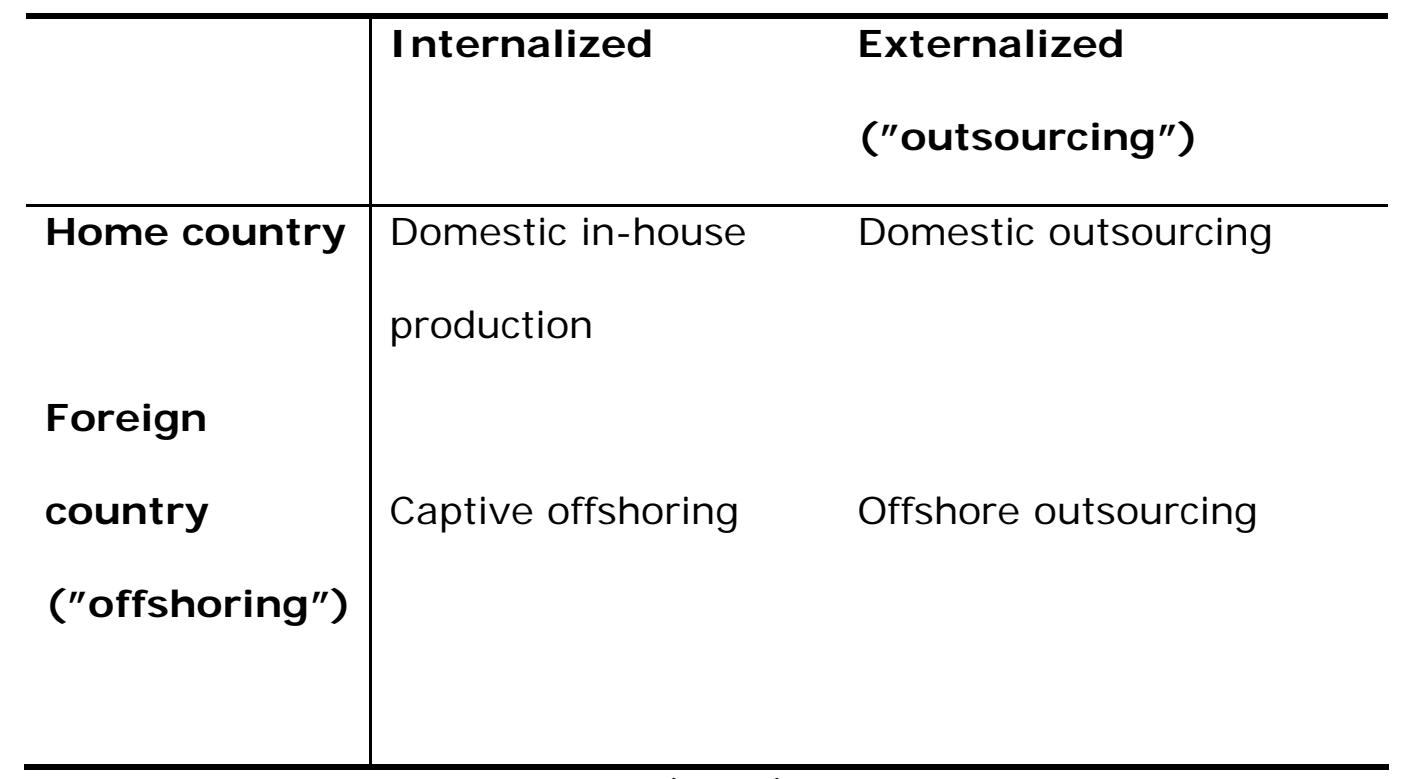

Source: Adapted after UNCTAD (2004) 
Table2 : Standardized versus I nnovative Activities

\begin{tabular}{|c|c|c|}
\hline & $\begin{array}{l}\text { Simple and } \\
\text { standardized tasks }\end{array}$ & $\begin{array}{l}\text { Complex and } \\
\text { advanced tasks }\end{array}$ \\
\hline R\&D & \multicolumn{2}{|c|}{ Test, patenting- } \\
\hline Production & \multicolumn{2}{|c|}{ Volume production- } \\
\hline Marketing & \multicolumn{2}{|c|}{ 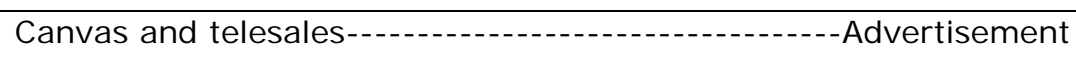 } \\
\hline IT & \multicolumn{2}{|c|}{ Service operations- } \\
\hline Administration & \multicolumn{2}{|c|}{ 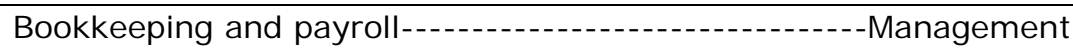 } \\
\hline
\end{tabular}


Table 3 Correlation matrix for all independent variables in the two models (the upper values are for model one and the lower values for model two)

1) Share of unskilled workers

2) Share of employee with an university degree

3) Capital-intensity

4) Motivated by lower labor costs

5) Motivated by access to new competences

6) Service firm (dummy)

7) Firm size

8) Financial performance

9) Multinational company (dummy)

Mean

Std. dev.
1

1.00

$-0.43 * * *$

$-0.45^{* * *} \quad 1.00$

$\begin{array}{ll}-0.001 & -0.03\end{array}$

$\begin{array}{lll}-0.01 & -0.01 & 1.00\end{array}$

$\begin{array}{llll}0.09 & -0.22 * * * & -0.02 & 1.00\end{array}$
2

3

4

5

6

7

8

$0.33 * * * 20$

$-0.33 * * *$

$-0.31 * * *$

$0.40 * * *$

0.07

$-0.21 * * *$

1.00

0.0

$0.31 * * *$

$-0.27 * * *$

$0.28 * * *$

1.00

0.01

$-0.04 \quad 0.10 * * *$

$0.10 *$

$-0.05$

0.03

$$
-0 .
$$

$-0.01$

$-0.07 \quad 0.18 * * *$

$0.01 \quad 0.22 * * *$

$-0.01$

$-0.01$

0.06

1.00

$-0.04$

$0.07 \quad 0.19 * * *$

(1)

0.03

1.00

$-0.04$

$0.09 * * * \quad 0.10 * * *$

$-0.07$

$0.13 * *$

0.002

$-0.01$

1.00

$\begin{array}{lll}-0.06 & 0.14 * * & 0.24 * * *\end{array}$

$0.14 * * *$

1.00

17.28

33.54

17.02

17.50

35.86

19.74

3.64

1.95

$-0.05^{*}$

1.00

27.70

36.66

28.13

26.15

35.38

30.85

1.50

1.30

$0.28 * * *$

$0.14 * *$

97.7

0.01

1.00

$\begin{array}{llll}0.56 & 97.7 & 0.20 & 0.25\end{array}$

0.52

206.8

0.07

0.50

0.50

502.0

1.10

0.43

0.50 
Table 4: Model for choice of Offshoring - Logistic regression (1.504 obs.)

\begin{tabular}{|c|c|}
\hline & Offshoring \\
\hline \multicolumn{2}{|l|}{ Cost related variables } \\
\hline Share of blue collar workers & $\begin{array}{c}0.001 \\
(0.001)\end{array}$ \\
\hline Share of white collar workers & $\begin{array}{c}-0.006 * * * \\
(0.002)\end{array}$ \\
\hline Capital-intensity & $\begin{array}{c}-0.003 * \\
(0.002)\end{array}$ \\
\hline \multicolumn{2}{|l|}{ Control-variables } \\
\hline Service firm & $\begin{array}{c}-0.40 * * * \\
(0.10)\end{array}$ \\
\hline Firm size & $\begin{array}{l}-0.45 \\
(0.35)\end{array}$ \\
\hline Financial performance & $\begin{array}{c}0.09 \\
(0.06)\end{array}$ \\
\hline Multinational company & $\begin{array}{c}0.74 * * * \\
(0.09)\end{array}$ \\
\hline Likelihood ratio & 151.9 ( 7 df.) $* * *$ \\
\hline Pseudo R-square & 10.5 \\
\hline
\end{tabular}


Table 5: Offshoring of advanced activities - OLS regression ( 346 obs.)

\begin{tabular}{|c|c|}
\hline & Offshoring of advanced activities \\
\hline \multicolumn{2}{|l|}{ Cost related variables } \\
\hline Share of blue collar workers & $\begin{array}{c}-0.006 * * \\
(0.003)\end{array}$ \\
\hline Share of white collar workers & $\begin{array}{c}0.008 * * * \\
(0.003)\end{array}$ \\
\hline Capital-intensity & $\begin{array}{c}0.003 \\
(0.003)\end{array}$ \\
\hline Lower labor costs & $\begin{array}{c}-0.10 * * \\
(0.06)\end{array}$ \\
\hline Access to new competences & $\begin{array}{c}0.19 * * * \\
(0.06)\end{array}$ \\
\hline \multicolumn{2}{|l|}{ Control-variables } \\
\hline Service firm & $\begin{array}{c}0.63 * * * \\
(0.18)\end{array}$ \\
\hline Firm size & $\begin{array}{c}0.12 * \\
(0.07)\end{array}$ \\
\hline Financial performance & $\begin{array}{c}-0.02 \\
(0.08)\end{array}$ \\
\hline Multinational company & $\begin{array}{c}-0.01 \\
(0.16)\end{array}$ \\
\hline F-value & $10.04 * * *$ \\
\hline Adjusted R-square & 21.4 \\
\hline
\end{tabular}


Table 6: Comparing results in the two models on offshoring

\begin{tabular}{|c|c|c|}
\hline & $\begin{array}{l}\text { Whether to offshore } \\
\text { (model } 1)\end{array}$ & $\begin{array}{l}\text { Offshoring of advanced } \\
\text { activities (model } 2 \text { ) }\end{array}$ \\
\hline \multicolumn{3}{|l|}{ Cost related variables } \\
\hline Share of blue collar workers & + & $-* *$ \\
\hline Share of white collar workers & $-* * *$ & $+* * *$ \\
\hline Capital-intensity & $-*$ & + \\
\hline Lower labor costs & & $-* *$ \\
\hline Access to new competences & & $+* * *$ \\
\hline \multicolumn{3}{|l|}{ Control-variables } \\
\hline Service firm & $-* * *$ & $+* * *$ \\
\hline Firm size & - & $+*$ \\
\hline Financial performance & + & - \\
\hline Multinational company & $+* * *$ & - \\
\hline
\end{tabular}

$*, * *$ and $* * *$ indicate a significance level of $10 \%, 5 \%$ and $1 \%$ respectively. 


\section{SMG - Working Papers \\ www.cbs.dk/smg \\ 2003}

2003-1: Nicolai J. Foss, Kenneth Husted, Snejina Michailova, and Torben Pedersen: Governing Knowledge Processes: Theoretical Foundations and Research Opportunities.

2003-2: Yves Doz, Nicolai J. Foss, Stefanie Lenway, Marjorie Lyles, Silvia Massini, Thomas P. Murtha and Torben Pedersen: Future Frontiers in International Management Research: Innovation, Knowledge Creation, and Change in Multinational Companies.

2003-3: Snejina Michailova and Kate Hutchings: The Impact of In-Groups and OutGroups on Knowledge Sharing in Russia and China CKG Working Paper.

2003-4: Nicolai J. Foss and Torben Pedersen : The MNC as a Knowledge Structure: The Roles of Knowledge Sources and Organizational Instruments in MNC Knowledge Management CKG Working Paper.

2003-5: Kirsten Foss, Nicolai J. Foss and Xosé H. Vázquez-Vicente: “Tying the Manager's Hands": How Firms Can Make Credible Commitments That Make Opportunistic Managerial Intervention Less Likely CKG Working Paper.

2003-6: Marjorie Lyles, Torben Pedersen and Bent Petersen: Knowledge Gaps: The Case of Knowledge about Foreign Entry.

2003-7: Kirsten Foss and Nicolai J. Foss: The Limits to Designed Orders: Authority under "Distributed Knowledge" CKG Working Paper.

2003-8: Jens Gammelgaard and Torben Pedersen: Internal versus External Knowledge Sourcing of Subsidiaries - An Organizational Trade-Off.

2003-9: Kate Hutchings and Snejina Michailova: Facilitating Knowledge Sharing in Russian and Chinese Subsidiaries: The Importance of Groups and Personal Networks Accepted for publication in Journal of Knowledge Management.

2003-10: Volker Mahnke, Torben Pedersen and Markus Verzin: The Impact of Knowledge Management on MNC Subsidiary Performance: the Role of Absorptive Capacity CKG Working Paper.

2003-11: Tomas Hellström and Kenneth Husted: Mapping Knowledge and Intellectual Capital in Academic Environments: A Focus Group Study Accepted for publication in Journal of Intellectual Capital CKG Working Paper.

2003-12: Nicolai J Foss: Cognition and Motivation in the Theory of the Firm: Interaction or "Never the Twain Shall Meet"? Accepted for publication in Journal des Economistes et des Etudes Humaines CKG Working Paper.

2003-13: Dana Minbaeva and Snejina Michailova: Knowledge Transfer and Expatriation Practices in MNCs: The Role of Disseminative Capacity.

2003-14: Christian Vintergaard and Kenneth Husted: Enhancing Selective Capacity Through Venture Bases. 


\section{4}

2004-1: Nicolai J. Foss: Knowledge and Organization in the Theory of the Multinational Corporation: Some Foundational Issues

2004-2: Dana B. Minbaeva: HRM Practices and MNC Knowledge Transfer

2004-3: Bo Bernhard Nielsen and Snejina Michailova: Toward a Phase-Model of Global Knowledge Management Systems in Multinational Corporations

2004-4: Kirsten Foss \& Nicolai J Foss: The Next Step in the Evolution of the RBV: Integration with Transaction Cost Economics

2004-5: Teppo Felin \& Nicolai J. Foss: Methodological Individualism and the Organizational Capabilities Approach

2004-6: Jens Gammelgaard, Kenneth Husted, Snejina Michailova: Knowledge-sharing Behavior and Post-acquisition Integration Failure

2004-7: Jens Gammelgaard: Multinational Exploration of Acquired R\&D Activities

2004-8: Christoph Dörrenbächer \& Jens Gammelgaard: Subsidiary Upgrading? Strategic Inertia in the Development of German-owned Subsidiaries in Hungary

2004-9: Kirsten Foss \& Nicolai J. Foss: Resources and Transaction Costs: How the Economics of Property Rights Furthers the Resource-based View

2004-10: Jens Gammelgaard \& Thomas Ritter: The Knowledge Retrieval Matrix: Codification and Personification as Separate Strategies

2004-11: Nicolai J. Foss \& Peter G. Klein: Entrepreneurship and the Economic Theory of the Firm: Any Gains from Trade?

2004-12: Akshey Gupta \& Snejina Michailova: Knowledge Sharing in Knowledge-Intensive Firms: Opportunities and Limitations of Knowledge Codification

2004-13: Snejina Michailova \& Kate Hutchings: Knowledge Sharing and National Culture: A Comparison Between China and Russia

\section{5}

2005-1: Keld Laursen \& Ammon Salter: My Precious - The Role of Appropriability Strategies in Shaping Innovative Performance

2005-2: Nicolai J. Foss \& Peter G. Klein: The Theory of the Firm and Its Critics: A Stocktaking and Assessment

2005-3: Lars Bo Jeppesen \& Lars Frederiksen: Why Firm-Established User Communities Work for Innovation: The Personal Attributes of Innovative Users in the Case of Computer-Controlled Music

2005-4: Dana B. Minbaeva: Negative Impact of HRM Complementarity on Knowledge Transfer in MNCs

2005-5: Kirsten Foss, Nicolai J. Foss, Peter G. Klein \& Sandra K. Klein: Austrian Capital Theory and the Link Between Entrepreneurship and the Theory of the Firm 
2005-1: Nicolai J. Foss: The Knowledge Governance Approach

2005-2: Torben J. Andersen: Capital Structure, Environmental Dynamism, Innovation Strategy, and Strategic Risk Management

2005-3: Torben J. Andersen: A Strategic Risk Management Framework for Multinational Enterprise

2005-4: Peter Holdt Christensen: Facilitating Knowledge Sharing: A Conceptual Framework

2005-5 Kirsten Foss \& Nicolai J. Foss: Hands Off! How Organizational Design Can Make Delegation Credible

2005-6 Marjorie A. Lyles, Torben Pedersen \& Bent Petersen: Closing the Knowledge Gap in Foreign Markets - A Learning Perspective

2005-7 Christian Geisler Asmussen, Torben Pedersen \& Bent Petersen: How do we Capture "Global Specialization" when Measuring Firms' Degree of internationalization?

2005-8 Kirsten Foss \& Nicolai J. Foss: Simon on Problem-Solving: Implications for New Organizational Forms

2005-9 Birgitte Grøgaard, Carmine Gioia \& Gabriel R.G. Benito: An Empirical Investigation of the Role of Industry Factors in the Internationalization Patterns of Firms

2005-10 Torben J. Andersen: The Performance and Risk Management Implications of Multinationality: An Industry Perspective

2005-11 Nicolai J. Foss: The Scientific Progress in Strategic Management: The case of the Resource-based view

2005-12 Koen H. Heimeriks: Alliance Capability as a Mediator Between Experience and Alliance Performance: An Empirical Investigation Into the Alliance Capability Development Process

2005-13 Koen H. Heimeriks, Geert Duysters \& Wim Vanhaverbeke: Developing Alliance Capabilities: An Empirical Study

2005-14 JC Spender: Management, Rational or Creative? A Knowledge-Based Discussion

\section{6}

2006-1: Nicolai J. Foss \& Peter G. Klein: The Emergence of the Modern Theory of the Firm

2006-2: Teppo Felin \& Nicolai J. Foss: Individuals and Organizations: Thoughts on a Micro-Foundations Project for Strategic Management and Organizational Analysis

2006-3: Volker Mahnke, Torben Pedersen \& Markus Venzin: Does Knowledge Sharing Pay? An MNC Subsidiary Perspective on Knowledge Outflows

2006-4: Torben Pedersen: Determining Factors of Subsidiary Development 
2006-5 Ibuki Ishikawa: The Source of Competitive Advantage and Entrepreneurial Judgment in the RBV: Insights from the Austrian School Perspective

2006-6 Nicolai J. Foss \& Ibuki Ishikawa: Towards a Dynamic Resource-Based View: Insights from Austrian Capital and Entrepreneurship Theory

2006-7 Kirsten Foss \& Nicolai J. Foss: Entrepreneurship, Transaction Costs, and Resource Attributes

2006-8 Kirsten Foss, Nicolai J. Foss \& Peter G. Klein: Original and Derived Judgement: An Entrepreneurial Theory of Economic Organization

2006-9 Mia Reinholt: No More Polarization, Please! Towards a More Nuanced Perspective on Motivation in Organizations

2006-10 Angelika Lindstrand, Sara Melen \& Emilia Rovira: Turning social capital into business? A study of Swedish biotech firms' international expansion

2006-11 Christian Geisler Asmussen, Torben Pedersen \& Charles Dhanaraj: Evolution of Subsidiary Competences: Extending the Diamond Network Model

2006-12 John Holt, William R. Purcell, Sidney J. Gray \& Torben Pedersen: Decision Factors Influencing MNEs Regional Headquarters Location Selection Strategies

2006-13 Peter Maskell, Torben Pedersen, Bent Petersen \& Jens Dick-Nielsen: Learning Paths to Offshore Outsourcing - From Cost Reduction to Knowledge Seeking

2006-14 Christian Geisler Asmussen: Local, Regional or Global? Quantifying MNC Geographic Scope

2006-15 Christian Bjørnskov \& Nicolai J. Foss: Economic Freedom and Entrepreneurial Activity: Some Cross-Country Evidence

2006-16 Nicolai J. Foss \& Giampaolo Garzarelli: Institutions as Knowledge Capital: Ludwig M. Lachmann's Interpretative Institutionalism

2006-17 Koen H. Heimriks \& Jeffrey J. Reuer: How to Build Alliance Capabilities

2006-18 Nicolai J. Foss, Peter G. Klein, Yasemin Y. Kor \& Joseph T. Mahoney:

Entrepreneurship, Subjectivism, and the Resource - Based View: Towards a New Synthesis

\section{7}

2007-1 Peter Abell, Teppo Felin \& Nicolai J. Foss: Building Micro-Foundations for the Routines, Capabilities, and Performance Links

2007-2 Michael W. Hansen, Torben Pedersen \& Bent Petersen: MNC Strategies and Linkage Effects in Developing Countries

2007-3 Niron Hashai, Christian G. Asmussen, Gabriel R.G. Benito \& Bent Petersen: Predicting the Diversity of Foreign Entry Modes

2007-4 Peter D. Ørberg Jensen \& Torben Pedersen: Whether and What to Offshore? 